\title{
QSAR Study of Quinazoline Derivatives as Inhibitor of Epidermal Growth Factor Receptor-Tyrosine Kinase (EGFR-TK)
}

\author{
La Ode Aman ${ }^{1 *}$, Widisusanti Abdulkadir ${ }^{2}$, Julitha Geybie Rembet ${ }^{2}$, Daryono H. Tjahjono ${ }^{3}$ \\ ${ }^{1}$ Department of Chemistry, Faculty of Mathematics and Natural Sciences, Universitas Negeri Gorontalo, Indonesia. \\ ${ }^{2}$ Department of Pharmacy, Faculty of Medical Sciences, Universitas Negeri Gorontalo, Gorontalo, Indonesia. \\ ${ }^{3}$ School of Pharmacy, Bandung Institute of Technology, Jalan Ganesha 10, Bandung 40132, Indonesia .
}

Received: 18 September, 2014 / Accepted: 30 November 2014

\begin{abstract}
:
Nowadays a lot of new active substances as anticancer cervix agents have been developed. One of the protein targets in discovery of anticancer cervix drugs is Epidermal Growth Factor Receptor-Tyrosine Kinase (EGFR-TK). In this present research the Quantitative Structure and Activity Relationship (QSAR) of quinazoline derivatives as inhibitors of EGFR-TK has been studied. Physicochemical parameters of quinazoline derivatives were calculated predictors to obtain the QSAR equation, and was then applied to predict the activity of new quinazoline derivatives. The best QSAR equation is $\mathrm{IC}_{50 \text {-pred }}=-(3.155 \pm 19.369) * \mathrm{glob}+(2.280 \pm 1.291)^{*} \mathrm{mr}-(0.136 \pm 0.103)^{*} \mathrm{TPSA}-$ $(1.599 \pm 2.585)^{*} \log \mathrm{P}-0.186 \pm 8.861$, with $\mathrm{n}=13, \mathrm{r}=0.896, \mathrm{r}^{2}=0.803, \mathrm{~F}_{\mathrm{cal}}=8.152, \mathrm{~F}=2.123, \mathrm{SE}=1.685, \mathrm{Sig}=0.006, \mathrm{q}^{2}=0.354 . \mathrm{Based}$ on the QSAR equation and by using the Topliss Scheme approach, three new quinazoline derivative showed higher inhibition activity than that of parent compound, and molecular docking study has shown the interaction between the those new ligand with active site of EGFR-TK.
\end{abstract}

Key words: Cervical cancer, EGFR-TK, molecular docking, QSAR, quinazoline, Topliss Scheme

\section{Introduction}

Cancer has caused high mortality in the world. Every year, 14.1 million have been indicated as cancer patients, and 8.2 million are died due to the cancer disease [1]. The main procedure in cancer treatment is surgery, irradiation and chemotherapy. Although chemotherapy can induce secondary primer cancer, it has advantage compare to that of surgery or radiation because of its ability to treat metastasis cancer, whereas surgery and radiation therapy is limited to certain areas [2].

Effort to discover new safe anticancer drugs, either natural or synthetic has been a big challenge for pharma companies as well as dedicated research center. In the past, drug discovery are based on trial and error so it was very expensive and took a long time to launch new chemical entity. Today, with the help of computer hardware and software, the process of discovery of new active substances is more effective in cost and time.

Quantitative Structure and Activity Relationship (QSAR) study is one approach in an effort to design and discover new active substances better than previous compounds by using computer program (in silico). In the present work, QSAR studies were performed using a data set of quinazoline derivatives synthesized by ElAzab et al [2]. Twenty-seven compounds of quinazoline derivatives were tested their antitumor activity against $\mathrm{HeLa}$ cells. The activity mechanism of these ligand series is by inhibiting Epidermal Growth Factor Receptor-Tyrosine Kinase (EGFR-TK)

\footnotetext{
* Corresponding author: La Ode Aman,

E-mail: laode_aman@ung.ac.id
}

through ATP binding pocket in the N-terminal domain mediated by water hydrogen bonds

\section{Experimental}

Data set

Twenty-seven of quinazoline derivatives with anticancer activity as synthesized and tested by ElAzab et al [2] were used as data set. The molecule structure and their activity are listed in Table 1.

\section{Calculation parameters}

Molecular structure was modeled by HyperChem ${ }^{\circledR}$ Release 8.0. All structure optimized by semi empirical AM1 method with gradient of $0.01 \mathrm{kcal} / \AA$. All descriptors were calculated using MOE 2007.09 the QSAR study. Those descriptors are partition coefficient $(\log P)$, solubility $(\log S)$, total energy $(E-$ tot), electronics energy (E-ele), HOMO energy (Е-номо), LUMO energy (E-Lumo), total dipole moment $(\mu)$, heat formation (HF), Van der Waals volume (Vw), globularity (GLOB), molar refractivity (mr), hydrophobic surface area (A) and total atomic polarizability.

\section{Statistical analysis}

Statistical analysis was performed by multilinear regression using SPSS Statistics 19 (IBM Software Trial). Dependent variable (Y) is the $\mathrm{FP} \mathrm{IC}_{50}$ obtained from experiments of each compound, while the independent variable (Xi) is the value of each predictor. 
Table 1. Data set of quinazoline derivative and their activity<smiles>COC1c2cc(Cl)ccc2N=C(c2ccc(C)cc2)N1C</smiles>

18.9

Q02<smiles>Cc1ccc(-c2nc3ccc(Cl)cc3c(=O)o2)cc1</smiles>

Q03<smiles>Cc1ccc(C(=O)Nc2ccc(Cl)cc2C(N)=O)cc1</smiles>

Q04<smiles>Cc1ccc(-c2nc3ccc(Cl)cc3c(=O)[nH]2)cc1</smiles>

8.23

8.23

Q16
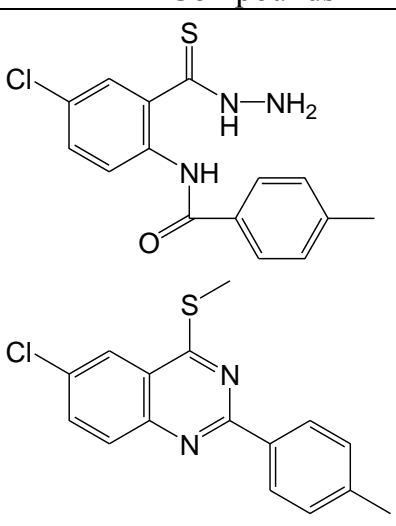

Q17

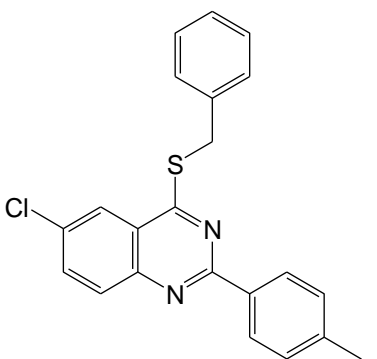

10.01

Q18<smiles>Cc1ccc(-c2nc(SC3CCCC([N+](=O)[O-])N3)c3cc(Cl)ccc3n2)cc1</smiles>

11.3

14.7

3.76

4.37

Q19<smiles>C=CCSc1nc(-c2ccc(C)cc2)nc2ccc(Cl)cc12</smiles><smiles>Cc1ccc(-c2nc3ccc(Cl)cc3c(=O)n2C)cc1</smiles>

Q06<smiles>Cc1ccc(-c2nc3ccc(Cl)cc3c(=S)[nH]2)cc1</smiles>

4.57

Q20<smiles>Cc1ccc(-c2nc(SC3CCCC([N+](=O)[O-])N3)c3cc(Cl)ccc3n2)cc1</smiles>

9.66

5.93<smiles>Cc1ccc(-c2nc(NC(=O)c3ccccc3)c3cc(Cl)ccc3n2)cc1</smiles>

3.56

Q21<smiles>Cc1ccc(-c2nc(SCCO)c3cc(Cl)ccc3n2)cc1</smiles>

9.25

115 
Table 1. Data set of quinazoline derivative and their activity (continued)

Q08<smiles>Cc1ccc(-c2nc(NO)c3cc(Cl)ccc3n2)cc1</smiles>

12.7

Q22

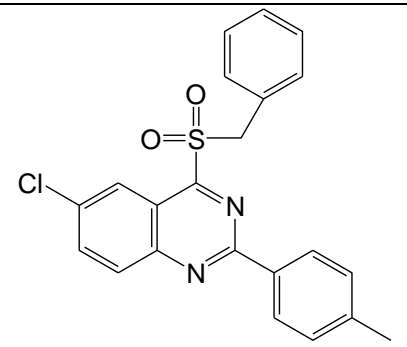<smiles>Cc1ccc(-c2nc(SCC(=O)Nc3ccccc3)c3cc(Cl)ccc3n2)cc1</smiles>

3.98

Q24

16.2

Q23
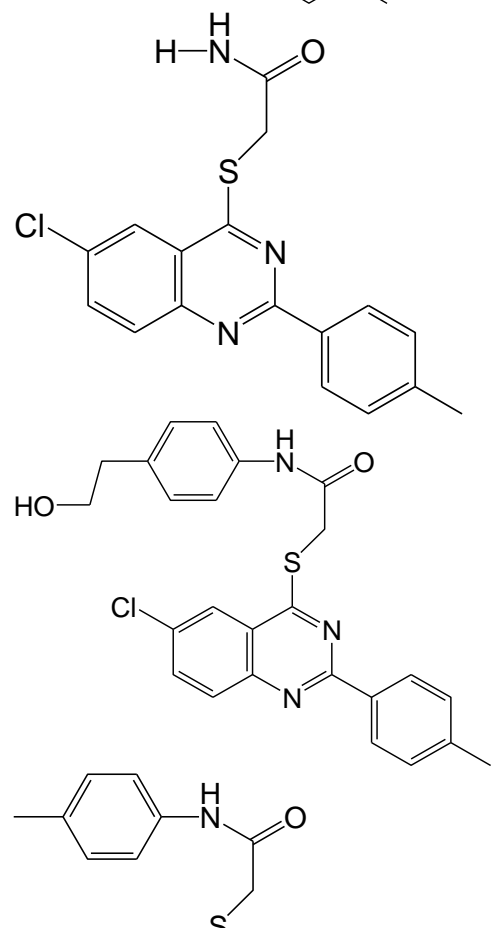

12.1

Q26

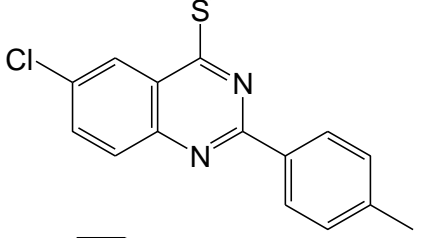

13.3

Q27<smiles>Cc1ccc(-c2nc(SCC(=O)Nc3ccc(F)cc3)c3cc(Cl)ccc3n2)cc1</smiles>

7.01

4.98

10.1

12.3

14.01

116 


\section{Validation}

Validation of QSAR equation was performed by using cross validation techniques with Leave One Out (LOO) approach. LOO cross validation squares $\left(\mathrm{q}^{2}\right)$ is an indicator of performance and stability model [3] which is calculated according to the following formula:

$$
\mathrm{q}^{2}=1-\frac{\sum\left(\mathrm{y}_{\mathrm{i}}-\widehat{\mathrm{y}}_{\mathrm{i}}\right)^{2}}{\sum\left(\mathrm{y}_{\mathrm{i}}-\overline{\mathrm{y}}\right)^{2}}
$$

where, $y_{i}=$ experimental activity, $\bar{y}_{i}=$ average of experimental activity, and $\hat{y}_{i}=$ cross validation of predictive activity for compound $i$.

By applying LOO, a selected model was obtained. The best QSAR equations have statistical criteria of $r^{2}$ $\geq 0.8$, and $\mathrm{q}^{2} \geq 0.5$. If the QSAR equations obtained does not fulfill these criteria, it means there is/are the outlier data which should be excluded

\section{Design of new derivatives}

There are three important measures in the design of new derivatives, namely (i) determining lead compound, (ii) selecting the substituents of lead compound which is replaced by a new substituent, and (iii) determine the list of new substituents. In this study, compound Q07 (Table 1) is a lead for designing new quinazoline derivatives. Substituents are selected for designing new compound using Topliss Scheme approach. It was obtained 10 new substituents as follow: $-\mathrm{H},-\mathrm{CH}_{3},-\mathrm{OCH}_{3},-\mathrm{CF}_{3},-\mathrm{NH}_{2},-\mathrm{OH}$, $\mathrm{OC}_{6} \mathrm{H}_{5},-\mathrm{NO}_{2},-\mathrm{CN},-\mathrm{COCH}_{3}$. Modification was conducted on $\mathrm{Cl}$ position so that obtained 10 new quinazoline derivatives.

\section{Molecular docking}

The study of ligands-EGFR-TK interaction was performed by using molecular docking techniques on Arguslab 4.0.1. There are two parameters which were observed in the molecular docking i.e. $\Delta G$ (free energy change) and hydrogen bonds formed between the ligand and the receptor (number of hydrogen bond and distance).

\section{Results and Discussion}

Statistical analysis was applied using multilinear regression with combination 2,3 , and 4 parameters as dependent variables and anticancer activity as independent variable. Statistical quality parameter using correlation coefficient (r), the square of the correlation coefficient $\left(\mathrm{r}^{2}\right)$, standard error (SE), the value of Fischer (F) and RMSE (root mean squared error) to test the model with the best regression equation. Highest $r, r^{2}, S E$, Fcal is/are the best model.

From the two model combination, it was then selected model 78 with $r$ and RMSE better than others. Model 78 is combination of 4 parameters: partition coefficient (log
P), Topology Surface Polar Regions (TPSA), Globularity (GLOB) and molar refractivity (mr) with QSAR equation as follows:

$$
\begin{aligned}
& \mathrm{IC}_{50} \text {-pred }=(47.495 \pm 27.605) * \mathrm{glob}-(3.517 \pm 1.802) * \mathrm{mr} \\
& +0.117 * \text { TPSA }+(0.3908 \pm 2.984) * \log \mathrm{P}+ \\
& \text { (17.117 } \pm 8.977) \quad \text { (eq. 1). } \\
& \text { with } r=4.30, r^{2}=0.185, \mathrm{SE}=4.1448281 \text {, Fcal }=1.25 \text {, } \\
& \mathrm{Sig}=0.319
\end{aligned}
$$

This QSAR equation is not fulfilled the statistical criteria, i.e. $r^{2}>0.8$. This is due to there are compounds that are used as the data sets are outliers. To get the best QSAR equation, the way is to remove the outlier compounds. In QSAR Tutorial of MOE 2007.09, the mentioned outliers data are datum which has Z-SCORE $\geq 2.5$.

After fourteen compounds outliers were removed, it was obtained a QSAR equation with good statistical parameters as follows:

$$
\begin{aligned}
\mathrm{IC}_{50} \text {-pred }= & (-3.155 \pm 19.369) * \mathrm{Glob}+(2.280 \pm 1.29) * \mathrm{Mr} \\
& -(0.136 \pm 0.103) * \text { TPSA }-1.599 \pm 2.585) * \log \\
& \mathrm{P}-(0.186 \pm 8.861)
\end{aligned}
$$

with $\mathrm{n}=13, \mathrm{r}=0.896, \mathrm{r}^{2}=0.803, \mathrm{~F}_{\mathrm{cal}}=8.152, \mathrm{~F}=2.123$, $\mathrm{SE}=1.6859896, \mathrm{~S}=0.006, \mathrm{q}^{2}=0.354093$

Thus, it showed that the four physicochemical properties of quinazoline derivatives which involved in acting as inhibitor of the EGFR-TK were topology of polar surface area, partition coefficient, globularity, and molar refractivity.

\section{Design of new derivatives}

The best QSAR equation was used as a basis for predicting activity of new quinazoline derivative which were estimated to have anticancer activity. The new quinazoline derivatives were obtained by substitution of $\mathrm{Cl}$ group in the lead compound with a groups of $-\mathrm{H},-\mathrm{CH}_{3},-\mathrm{OCH}_{3},-\mathrm{CF}_{3},-\mathrm{NH}_{2},-\mathrm{OH}$, $-\mathrm{OC}_{2} \mathrm{H}_{5},-\mathrm{NO}_{2},-\mathrm{CN}$, and $-\mathrm{COCH}_{3}$, thus afforded ten new quinazoline derivatives. Using parameters of $\mathrm{mr}$, TPSA, glob and $\log \mathrm{P}$ as described in QSAR equation (Eq. 2), it will then be obtained theoretical or predictive anticancer activity $\left(\mathrm{IC}_{50}\right.$ pred.) of each new derivative as shown in Table 2.

Table 2 shows there are three derivatives which have better activity than that of lead compound $\left(\mathrm{IC}_{50}=\right.$ 3.56). They are QD05, QD06 and QD09.

The molecular structure and anticancer activity of those compounds and their theoretically activity are shown in Fig. 1, 2 and 3. 
Table 2. Predictors' values and IC50-pred of new compounds of quinazoline derivatives

\begin{tabular}{cccccc}
\hline Derivatives & $\mathrm{mr}$ & TPSA & glob & Log P & IC $_{50 \text {-pred }}$ \\
\hline QD01 & 7.2226 & 51.8000 & 0.0041 & 2.9870 & 4.4474 \\
QD02 & 7.6694 & 51.8000 & 0.0062 & 3.3220 & 4.9240 \\
QD03 & 7.9058 & 61.0300 & 0.0058 & 2.9800 & 4.7558 \\
QD04 & 7.7891 & 51.8000 & 0.0078 & 3.9588 & 4.1737 \\
QD05 & 7.4750 & 77.8200 & 0.0034 & 2.3520 & 2.5019 \\
QD06 & 7.3983 & 72.0300 & 0.0037 & 2.7160 & 2.5315 \\
QD07 & 9.9269 & 61.0300 & 0.0016 & 4.6340 & 6.7324 \\
QD08 & 7.7857 & 100.7800 & 0.0030 & 2.9590 & -0.8816 \\
QD09 & 7.7991 & 75.5900 & 0.0036 & 2.6840 & 3.0126 \\
QD10 & 8.3807 & 61.0300 & 0.0140 & 3.1140 & 5.5983 \\
\hline
\end{tabular}<smiles>CNc1nc(-c2ccc(C)cc2)nc2ccc(N)cc12</smiles>

Figure 1. QD05 with $\mathrm{IC}_{50 \mathrm{pred}}=2.532$

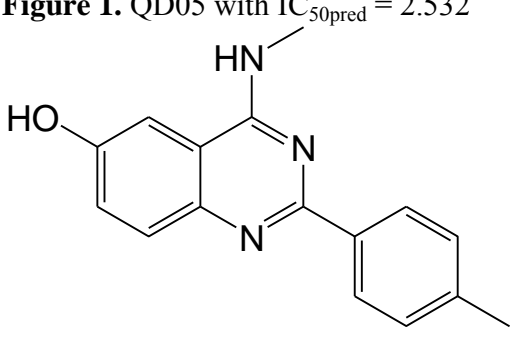

Figure 2. QD06 with $\mathrm{IC}_{50}$ pred $=2.532$<smiles>CNc1nc(-c2ccc(C)cc2)nc2ccc(C#N)cc12</smiles>

Figure 3. QD06 with $\mathrm{IC}_{50 \text {-pred }}=2.532$

Molecular docking aims to study the interaction of ligands with receptor. Three new compounds quinazoline derivative (QD05, QD06, and QD09) are studied the interaction between ligand and with EGFRTK protein. By using software ArgusLab molecular docking results obtained are summarized in Figure 4 and Table 3 show interaction between QD09 and binding site of EGFR-TK.

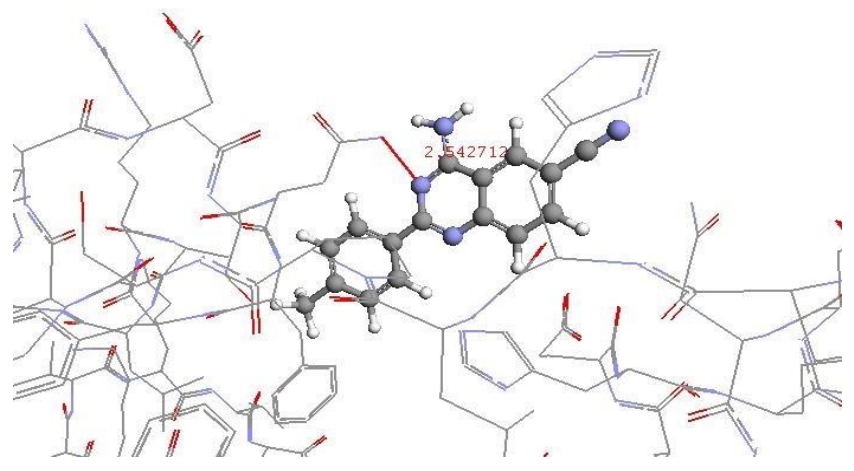

Figure 4. Interaction between QD09 on binding site of EGFRTK

Best ligand energy pose describes the free energy $(\Delta G)$ in which $\Delta G$ is a parameter related to the reactivity of a compound with a receptor. According to Sellasie [4], the spontaneity of the reaction between the compounds with receptor occurs with a decrease in free energy. It means that the more negative of free energy of a compound, the higher the spontaneity of the reaction between compounds with the receptor.

Table 3 shows that all three new derivatives have a marked negative (-) $\Delta G$. Thus, these ligands have the ability to bind to the EGFR-TK binding site.

\section{Conclusion}

The best QSAR equation for quinazoline derivatives as inhibitor of EGFR-TK is $\mathrm{IC}_{50}$-pred $=(-3.155$ $\pm 19.369) *$ glob $\quad+\quad(2.280 \pm 1.291) * \mathrm{mr} \quad-$ $(0.136 \pm 0.103) *$ TPSA $-(1.599 \pm 2.585)^{*} \log \mathrm{P}-$ $0.186 \pm 8.861$, with $\mathrm{n}=13, \mathrm{r}=0.896, \mathrm{r}^{2}=0.803, \mathrm{~F}_{\mathrm{cal}}=$ $8.152, \mathrm{~F}=2.123, \mathrm{SE}=1.6859896, \mathrm{Sig}=0.006, \mathrm{q}^{2}=$ 0.354093 . Three new quinazoline derivatives are predicted to have anticancer cervix activity through inhibition of EGFR-TK. 
Table 3. Parameters of the interaction between quinazoline derivatives and EGFR-TK

\begin{tabular}{|c|c|c|c|c|c|c|c|}
\hline \multirow{2}{*}{ Ligand } & \multirow{2}{*}{$\mathrm{IC}_{50 \text {-pred }}$} & \multirow{2}{*}{$\Delta \mathrm{G}$} & \multirow{2}{*}{ Numbers of $\mathrm{H}_{\text {bond }}$} & \multicolumn{2}{|c|}{ Atom Binding } & \multirow{2}{*}{ Receptor residues } & \multirow{2}{*}{ Bond length } \\
\hline & & & & Ligand & Receptor & & \\
\hline QD05 & 2.57 & -6.15 & - & - & - & - & - \\
\hline \multirow{2}{*}{ QD06 } & \multirow{2}{*}{3.17} & \multirow{2}{*}{-6.86} & \multirow{2}{*}{2} & N (11) & $\mathrm{N}$ & 990 PRO & 2.865505 \\
\hline & & & & $\mathrm{O}(7)$ & $\mathrm{O}$ & 994 ASP & 2.054839 \\
\hline QD09 & 3.32 & -6.90 & 1 & $\mathrm{~N}(8)$ & $\mathrm{N}$ & 996 ASN & 2.542712 \\
\hline
\end{tabular}

\section{Acknowledgment}

LOA thanks the State University of Gorontalo for financial support for participating in ICCST-3 2014 in Bali, Indonesia.

\section{References}

[1] IARC 2012 Report (http://globocan.iarc.fr; fact sheet).

[2] El Azab, et. al., Design, synthesis and biological evaluation of novel quinazoline derivatives as potential antitumor agents: Molecular docking study, European journal of Medicinal Chemistry, 45, 2010, 4188-4198.

[3] C. Jin Can, Q. Li, S. Yong, C. Lan Mei, Z. Kang Cheng, A QSAR study and molecular design of benzothiazole derivatives as a potent anticancer agents. Sci. in China Ser. $B, \mathbf{5 1}(2), 2008,111-119$.

[4] Selassie, History of quantitative structure-activity relationships, Department of Chemistry, Pomona College Claremont, California, Burger Medicinal Chemistry and Drug Discovery, 2003. 